\title{
COMPARATIVE STUDY OF PULMONARY FUNCTION IN TYPE I AND TYPE II DIABETICS
}

\author{
Ratnesh N Gajbhiye ${ }^{1}$, Mangesh A Bankar *2. \\ ${ }^{1}$ Associate professor in Physiology, ANIIMS, Port Blair, India. \\ ${ }^{* 2}$ Associate professor in Pharmacology, ANIIMS, Port Blair, India. \\ ABSTRACT
}

Background: Diabetes is a disease involving almost each and every organ of our body. When blood glucose level remain chronically elevated, glycosylation of tissue proteins occur leading to irreversible changes in the chemical structure of tissue proteins. Protein containing tissues such as skin, muscles, kidneys, peripheral nerves, respiratory system, vascular bed, etc. are the prime targets for glycosylation. The functional status of the lungs can be fairly evaluated with the help of a spirometer which gives fairly good results. Present study was undertaken to compare the pulmonary functions in type I and type II diabetics.

Materials and Method: 60 type I and 60 type II diabetic subjects were randomly selected for the study. Anthropometric parameters, blood investigations and spirometry was performed on all the subjects.

Result: Fasting and Post Meal blood glucose levels were higher in both the groups but were non significant when compared with each other. $\mathrm{HbA}_{1} \mathrm{c} \%$ was on the higher side in both groups but was significantly higher in type I diabetics as compared to type II diabetics. All P.F.T. parameters were reduced in type I diabetics, but FVC, $\mathrm{FEV}_{1}$ and FEF $0.2-1.2 \mathrm{~L}$ were significantly reduced as compared to type II diabetics.

Conclusion: We observed a decrease in pulmonary function in all the diabetic subjects in the form of restrictive lung pathology, but the type I subjects are more severely affected than type II. Hence, we recommend regular testing of $\mathrm{HbA} \quad \mathrm{c} \%$ and P.F.T. to find out early deterioration of lungs in diabetic patients.

KEY WORDS: Type I Diabetes, Type II Diabetes, Pulmonary Function Test, Nonenzymatic Glycosylation.

Address for correspondence: Dr. Mangesh A Bankar, Associate Professor in Pharmacology, ANIIMS, Port Blair, India. E-Mail: drmbankar@gmail.com

\begin{tabular}{|c|c|c|}
\hline \multicolumn{3}{|c|}{ Online Access and Article Informtaion } \\
\hline \multirow{3}{*}{$\begin{array}{l}\text { Quick Response code } \\
\text { DOI: } 10.16965 / \text { ijims.2018.118 }\end{array}$} & \multicolumn{2}{|c|}{$\begin{array}{l}\text { International Journal of Integrative Medical Sciences } \\
\text { ISSN (P): } 2394 \text { - 6318. ISSN (E): } 2394-4137 \\
\text { www.imedsciences.com }\end{array}$} \\
\hline & Received: 08-06-2018 & Accepted: 13-06-2018 \\
\hline & Reviewed: 08-06-2018 & Published: 05-07-2018 \\
\hline Source of Funding: Self & \multicolumn{2}{|c|}{ Conflicts of interest: None } \\
\hline
\end{tabular}

\section{BACKGROUND}

Diabetes mellitus is one of the leading causes of death worldwide because of the chronic complications associated with sustained elevated blood glucose levels. Many organs are the targets for this chronic hyperglycemia including blood vessels, kidney, eyes, nerves, etc. But Schuyler et al were the first to state that the lung may also be affected in diabetes in 1976 [1]. Since then many studies have been done to access the degree of damage to the lung in diabetics. Lungs may also be the target in diabetes as it also contains collagen and elastic fibers that are susceptible for non-enzymatic glycosylation due to chronic hyperglycemia. There are various studies of pulmonary function test in type I and type II diabetics with conflicting results. But there are very few studies to access the magnitude of lung damage between the two types of diabetics patients. Hence the present study was undertaken to evaluate the severity of lung damage between type I and type Il diabetics. 


\section{MATERIALS AND METHODS}

Subjects: The present study was carried out in the Diabetic Clinic of I.G.G.M.C. Nagpur. The Institutional ethics committee approval was obtained. Informed written consent was obtained from all the subjects participating in the study. All subjects were males in the age group of 31- 60 years. Based on the treatment received, the subjects were divided into two groups. Those receiving only insulin therapy were grouped as type I diabetics and those receiving only oral anti-diabetic drugs were grouped as type II diabetics. All the subjects were supplied with a respiratory questionnaire [2]. Clinical evaluation to rule out respiratory, cardiac or other diseases that may contraindicate pulmonary function testing was done by the Physician. All subjects were non-smokers with no past history of smoking. After selection, all subjects were asked to report to the Dept. of Physiology, I.G.G.M.C. Nagpur in the morning hours (8 A.M. -11 A.M.) to undergo the various tests.

Anthropometric measurements: A measuring scale was inscribed on the wall against which the subjects were made to stand bare foot to measure standing height. Weight was done on a weighing machine in light weight garments without foot wears. Using Dubois and Dubois equation (1936), BSA was calculated [3]. BMI was calculated using formula: $\mathrm{BMI}=$ Weight in kg / (Height in meter) ${ }^{2}$.

Biochemical profile: Fasting and post meal blood glucose level was measured using Glucose Oxidase Biosensor assay method by One Touch Horizon Glucose Meter. $\mathrm{HbA}$ c\% was measured using cation exchange resin method (monozyme's glycohemin kit).

Measurement of lung volumes: P.F.T. was measured using MEDSPIROR - Recorder and Medicare system. Necessary instructions were given to the subjects before performing P.F.T. They were asked to perform forceful expiration at the end of deep full inspiration. The subjects were made accustomed to the procedure before taking the final reading. Best of three readings was selected for the study. One single expiratory effort gives many readings but, only FVC, FEV , FEV \%, FEF 25-75\%, FEF 0.2-1.2L, PEFR were selected for the study. After the rest for 15 minutes Maximum Ventilation Volume (MVV) was measured. Subjects were asked to inhale and exhale as fast and as deep as possible for twelve seconds. The inbuilt software in the Medspiror gives the MVV values in liters per minute. Test for MVV was repeated 3 times with a rest of 10 minutes in between each reading. Best of the three readings was selected for the study.

Statistical Analysis: Mean \& Standard Deviation were calculated and significance of difference was tested by applying unpaired student's t test [4].

\section{RESULTS}

The results of the study are shown in the tables below.

Table 1: Showing comparison of anthropometric parameters between type I and type II diabetics. (Values are expressed as Mean \pm SD).

\begin{tabular}{|c|c|c|}
\hline Parameter & Type I Diabetics & Type II Diabetics \\
\hline Age (yrs) & $50.20 \pm 5.92$ & $50.70 \pm 6.15$ \\
\hline Weight (kg) & $58.90 \pm 9.11$ & $58.50 \pm 8.18$ \\
\hline Height (meter) & $1.62 \pm 0.04$ & $1.62 \pm 0.05$ \\
\hline B.M.I. $\left(\mathrm{Kg} / \mathrm{m}^{2}\right)$ & $22.40 \pm 3.32$ & $22.3 \pm 2.35$ \\
\hline B.S.A. $\left(\mathbf{m}^{2}\right)$ & $1.61 \pm 0.12$ & $1.60 \pm 0.13$ \\
\hline
\end{tabular}

Table 2: Showing comparison of blood parameters between type I and type II diabetics. (Values are expressed as Mean \pm SD).

\begin{tabular}{|c|c|c|}
\hline Parameter & Type I Diabetics & Type II Diabetics \\
\hline Fasting (mg \%) & $175.30 \pm 59.65$ & $157.3 \pm 53.43$ \\
\hline Post Meal (mg \%) & $281.9 \pm 71.18$ & $250.60 \pm 90.72$ \\
\hline${ }^{*} \mathrm{HbA}_{1} \mathrm{c} \%$ & $9.21 \pm 1.42$ & $8.20 \pm 1.72$ \\
\hline
\end{tabular}

Table 3: Showing comparison of P.F.T. parameters between type I and type II diabetics. (Values are expressed as Mean \pm SD).

\begin{tabular}{|c|c|c|}
\hline Parameter & Type I Diabetics & $\begin{array}{c}\text { Type II } \\
\text { Diabetics }\end{array}$ \\
\hline * FVC (Litre) & $2.26 \pm 0.38$ & $2.73 \pm 0.5$ \\
\hline * $\mathrm{FEV}_{1}$ (Litre) & $1.96 \pm 0.29$ & $2.21 \pm 0.4$ \\
\hline$*$ FEV $_{1} \%$ & $87.2 \pm 5.96$ & $84.7 \pm 3.99$ \\
\hline $\begin{array}{c}\text { FEF } 25 \text { - } 75 \% \\
\text { (L/sec) }\end{array}$ & $2.65 \pm 0.7$ & $2.72 \pm 0.54$ \\
\hline $\begin{array}{c}\text { * FEF } 0.2-1.2 \mathrm{~L} \\
(\mathrm{~L} / \mathrm{sec})\end{array}$ & $3.76 \pm 1.19$ & $4.8 \pm 1.14$ \\
\hline PEFR (L/sec) & $5.37 \pm 1.49$ & $5.94 \pm 1.15$ \\
\hline MVV (L/min) & $89.9 \pm 14.86$ & $91.33 \pm 19.01$ \\
\hline
\end{tabular}

$* \mathrm{p}<0.05$ (significant)

\section{DISCUSSION}

Anthropometric parameters were found to be 
non significant between type I and type II diabetics. Fasting and post meal blood glucose levels were elevated in both groups but it was non significant. HbA c\% was also elevated in both groups indicating that there was poor glycemic control, and it was significantly increased in type I diabetics as compared to type Il diabetics. This may be because of inappropriate doses of insulin, irregular diet, lack of diabetic life style discipline, etc. followed by the patients. $\mathrm{HbA} \mathrm{c}$ is an indicator of diabetic control and provides the average blood glucose level during the past $2-3$ months. Higher is the $\mathrm{HbA} \quad \mathrm{c} \%$, poor is the diabetic control. If blood glucose remains chronically elevated for a long time, it leads to more and more non-enzymatic glycosylation of tissue proteins. Hence, if respiratory system is also considered to be one of the target organ for diabetes, then this should reflect in the P.F.T. parameters that were analyzed in the present study.

All the P.F.T. parameters except FEV \% were decreased in both groups but the magnitude of decrease was more in type I diabetics as compared to type II, may be because of the long duration of the disease and the poor control of blood glucose level in them as evident by the significantly elevated levels of $\mathrm{HbA} \mathrm{C} \%$. FVC and FEV were significantly decreased in type I diabetics as compared to type II diabetics. But FEV \% was significantly increased in type I diabetics. This indicates that in diabetes, restrictive lung pathology is produced due to non enzymatic glycosylation of collagen and elastic tissues present in the respiratory apparatus leading to a less compliant lung. Similar findings were observed by other authors [5-14]. FEF $25-75 \%$ is an indicator of forceful expiration of air during middle $50 \%$ of forced expiration.

Decrease in muscular and recoiling forces of the respiratory system because of increased glycosylation is responsible for decrease in FEF $25-75 \%$ in diabetics $[5,12,15]$. The decrease was non significant between the two groups. FEF $0.2-1.2 \mathrm{~L}$ is the volume of air expired during forced expiration. First $200 \mathrm{ml}$ of the gas is from the dead space. Remaining 1 litre is exhaled from broncho-alveolar tree. This includes some gas from functional residual capacity as normal tidal volume is $500 \mathrm{ml}$. This expulsion of gas from the functional residual capacity is due to compression of the lungs by the expiratory muscles during forced expiration. But due to glycosylation of connective tissues of the respiratory apparatus (lungs and respiratory muscles), compression forces required for expulsion of gas from functional residual capacity might be reduced, leading to a decrease in FEF 0.2-1.2 L in diabetics and is significantly decreased in type I subjects as compared to type II for reasons mentioned above. PEFR is gas exhaled in $1 / 10$ th of a second during forced expiration. During this time, the contractile forces of respiratory muscles and recoil forces of the lungs are functioning to their maximum and supporting the expiration to the maximum. But due to glycosylation of connective tissues of the respiratory apparatus, the recoil \& muscular forces of the lung and the respiratory system for expiratory purpose might be reduced, leading to a decreased PEFR in the diabetics $[12,14]$.

In the present study, the decrease was found to be non significant between the two groups. In MVV, maximum ventilatory efforts are to be made. MVV is decreased in diabetics $[8,11]$, indicating that muscular forces are weakened causing decrease in lung compliance which is again due to glycosylation of connective tissues of the respiratory apparatus. The decrease was non significant between the two groups. Amal Abd El-Azeem et al. [16] also observed a decrease in pulmonary function in type I diabetics as compared to type II diabetics.

So the message through the present work is that there is deterioration of lung function in the diabetics, in the form of a restrictive lung pathology. The deterioration is more pronounced in type I diabetics as compared to type II diabetics for reasons mentioned above. The restrictive pathology is because of overall effect of glycosylation on the collagen and elastic framework of the respiratory apparatus [8]. Since the collagen and elastic tissues are present in the, fascia, joints, skin, muscles, lung parenchyma and pleura, there is overall damage to the respiratory apparatus $[9,10]$. These micro damages produce a less compliant lung. But the weakness of respiratory muscles is not much appreciated by the patient in routine life, as during normal tidal respiration, diaphragm is the 
only muscle used and tidal work load on non-diaphragmatic respiratory muscles (i.e. intercostal muscles) is comparatively less. This does not mean that the respiratory muscles are not weakened in diabetes. The force building ability of respiratory musculature decreases in diabetes but, magnitude of restriction will depend upon individual susceptibility and susceptibility of the lungs.

\section{CONCLUSION}

The present study has shown a decrease in pulmonary function in all the diabetic subjects in the form of restrictive lung pathology, but the type I subjects are more severely affected than type II. Hence, it is recommended to test $\mathrm{HbA}$ c\% and P.F.T. at regular intervals to detect early deterioration of lungs in diabetic patients.

\section{REFERENCES}

[1]. Schuyler M.R., Niewoechner D.E., Inkley S.R. and Kohn R. Abnormal lung elasticity in juvenile diabetes mellitus. American Review of Respiratory Diseases 1976; 113: 37- 41.

[2]. Fishman A.P. Pulmonary diseases and disorders. 2nd edition, 1988; Vol. I, Appendix A. pp 34, Vol III pp. 2492.

[3]. Dubois .Dubois body surface chart Table ' $A$ ' as prepared by Boothy and Sandi fort of the Mayo clinical. Am. J. of Physiol. July 1936.

[4]. Mahajan B.H. and Gupta M.C. Textbook of preventive and social medicine 2nd edition, 1995; 414 46.

[5]. Ramirez LC, Nogare AD, Hsia C and Arauz C. Relationship between diabetes control and pulmonary function in IDDM. The American Journal of Medicine, 1991; 91:371-76.

[6]. Bell D, Collier A, David M, Matthews, Elizabeth JC, Ross Mchardy GJ and Clarke BF. Are reduced lung volumes in IDDM due to defect in connective tissue? Diabetes 1988; 37:829-31.
[7]. Lange P, Groth S, Kastrup J, Mortensen J, Appleyard $M$, Nyboe J, Jensen $G$ and Schnohr P. Diabetes mellitus, plasma glucose and lung function in a cross sectional population study. Eur. Respir. J 1989; 2:1419.

[8]. Heimer D, Brami J, Lieberman D and Bark H. Respiratory muscle performance in patients with type 1 diabetes. Diabetic Medicine 1990; 7:434-37.

[9]. Schnack Ch, Festa A, Schwarzmaier D and Assie'a. Pulmonary dysfunction in type 1 diabetes in relation to metabolic long term control and to incipient diabetic nephropathy. Nephron 1996;74: 395-400.

[10]. Schnapf BM, Banks RA, Silverstein JH, Rosenbloom AL, Chesrown SE and Louglin GM. Pulmonary function in insulin dependent diabetes mellitus with limited joint mobility. Am. Rev. Respir. Dis. 1984; 130: 930-32.

[11]. Wanke T, Formanek D, Auinger M, Popp W, Zwick H and Irsigler K. Inspiratory muscle performance and pulmonary function changes in insulin dependent diabetes mellitus. Am. Rev. Respir. Dis. 1991; 143:97100.

[12]. Makkar P, Gandhi M, Agrawal RP, Sabir M and Kothari RP. Ventilatory pulmonary function tests in type 1 diabetes mellitus. JAPI, 2000; 48(10): 962-966.

[13]. Irfan M, Jabbar A, Haque AS, Awan S and Hussain SF. Lung India, 2011; 28(2):88-92.

[14]. Meo SA, Al-Drees AM, Shah SF, Arif M, Al- Rubean K. Lung function in type 1 Saudi diabetic patients. Saudi Med J 2005; 26:1728-33.

[15].Sreeja CK, Samuel E, Kesavachandran C and Shashidhar S. Pulmonary function in patients with diabetes mellitus. Indian J. Physiol. Pharmacol. 2003; 47(1): 87-93.

[16]. Amal Abd El-Azeem, Gehan Hamdy, Mohamed Amin, Alaa Rashad. Pulmonary function changes in diabetic lung. Egyptian Journal of Chest Diseases and Tuberculosis. 2013; 62:513-517.

How to cite this article: Ratnesh N Gajbhiye, Mangesh A Bankar. COMPARATIVE STUDY OF PULMONARY FUNCTION IN TYPE I AND TYPE II DIABETICS. Int J Intg Med Sci 2018;5(6):655-658. DOI: 10.16965/ ijims.2018.119 